\title{
SOIL SPECTRAL MAPPING AND ITS CORRELATION WITH THE TRADITIONAL METHODOLOGY
}

\author{
Mapeamento espectral de solos e sua correlação com a metodologia tradicional \\ Marcelo Luiz Chicati ${ }^{1}$ - ORCID: 0000-0003-1631-3709 \\ Marcos Rafael Nanni² - ORCID: 0000-0003-4854-2661 \\ Everson Cézar² - ORCID: 0000-0001-8042-090X \\ Roney Berti de Oliveira ${ }^{1}$ - ORCID: 0000-0002-7338-2666 \\ Mônica Sacioto Chicati² - ORCID: 0000-0001-5353-4135 \\ ${ }^{1}$ Universidade Estadual de Maringá, Departamento de Engenharia Civil, Maringá - Paraná, Brasil. \\ E-mail: mlchicati@uem.br; rboliveira@uem.br \\ ${ }^{2}$ Universidade Estadual de Maringá, Departamento de Agronomia, Maringá - Paraná, Brasil. \\ E-mail: mrnanni@uem.br; eversoncezar@yahoo.com.br; monicasacioto@gmail.com
}

Received in August 24 ${ }^{\text {th }}, 2016$

Accepted in April 05 $5^{\text {th }}, 2018$

\section{Abstract:}

The use of remote sensing is increasing in agriculture and this raises questions about its efficiency over other usual methods. Thus, the purposes of this study were to compare methodologies for soil mapping, using field samplings and spectral data (from laboratory and from a simulated Landsat-TM), and to estimate their correlation. The soil samples were collected in a wetland with a great variety of soil classes. The distribution of soil classes in the maps was based on independence analysis by the Chi-square. Ten soil classes were determined in the study area, 6 in the first category level. The map of laboratory spectral data showed low correlation with conventional data. The map of spectral data that simulated wavelenghts corresponding the spectral bands of Landsat-TM sensor showed the same behavior of the previous map, with lower correlation with the conventional data. Thus, we verified that the mapping of paddy soils with spectral data shows low correlation with conventional data, however, still rather positive.

Keywords: Remote sensing; Pedology; Wetlands; Geoinformation.

\section{Resumo:}

A utilização do sensoriamento remoto cresce cada vez mais na agricultura e isso promove questionamentos sobre sua eficiência em relação aos demais métodos usuais. Assim, o objetivo deste estudo foi comparar metodologias de mapeamento de solos, usando amostras de campo e dados espectrais (de laboratório e de uma simulação Landsat-TM) para estimar esta correlação. As amostras de solo utilizadas foram coletadas em região de várzea com grande variedade pedológica. A distribuição das classes de solo nos mapas foi baseada em análise de independência

How to cite this article: Chicati, M. L., et al. Soil spectral mapping and its correlation with the traditional methodology. Bulletin of Geodetic Sciences, Vol. 24, issue 2, 202-216, Apr-Jun, 2018. 
por Qui-quadrado. Foram determinadas 10 classes de solos na área de estudo, sendo seis no primeiro nível categórico. O mapa de solos com dados espectrais de laboratório apresentou baixa correlação com os dados convencionais. O mapa de dados espectrais, simulando os comprimentos de onda correspondentes às bandas do sensor Landsat-TM demonstrou distribuição semelhante ao mapa anterior, com menor correlação ao método convencional. Assim, verifica-se que o mapeamento de solos de várzea com os dados espectrais mostra baixa correlação com os dados convencionais, porém, ainda assim estatisticamente significativo.

Palavras-chave: Sensoriamento remoto; Pedologia; Zonas úmidas; Geoinformação

\section{Introduction}

Hand-held spectroscopy, also known as hyperspectral remote sensing is a technique that has been widely used in agriculture (Munyati 2000; Brandão et al. 2006). Such measurements are useful not only for mapping of soil classes, but also to environmental analysis, urban monitoring, disaster control and forecasting, among others (Chicati et al. 2008). Conventional soil mapping methods based on field data collection and posterior data compilation using pre-existing information are generally more expensive, laborious and time-consuming when compared to the mapping of modern techniques that use Geographic Information Systems (GIS) and Digital Imaging (DI) (Demattê et al. 2004). Sousa Junior et al. (2008) justify the use of spectral data according to user's needs, especially when targets are located on difficult access areas.

In this sense, the techniques of diffuse spectroradiometry are presented as a method of obtaining reliable results, because the management of soil properties is non-destructive and can be applied in studies of short or medium term, such as mappings made using geostatistical techniques or even based on hyperspectral sensors (Zelikman and Carmina 2013; Franceschini et al. 2015; Arruda et al. 2016). Advances in digital soil mapping like digital spatial data (DEM, orbital images), the computer power to process large data or the progress of GIS tools are attracting new soil scientists by the spatial analyses of soils (Minasny and McBratney 2016). However, to prove the method's effectiveness the comparison of data obtained by spectral method should be done with laboratory data (Nanni and Demattê 2006) instead of data coming from satellite images, for example.

Based on spectral processes and methodologies available for research, this work was developed in the hypothesis that it is possible to map soils and determine their spatial distribution in areas destined to the irrigated paddy plantation using diffuse reflectance spectroscopy. There is a lack of studies regarding to lowland soils which is even more significant since others papers related to this topic (Nanni et al. 2004; Chicati et al. 2008; Fiorio and Demattê 2009) deal with specific and different environmental conditions of this. Accordingly, a lowland area with various soil classes was chosen to test the effectiveness of the method (Chicati et al. 2010). The objective of this study was to compare soil mapping methodologies. The conventional methodology, based on field sample collection followed by physical and chemical laboratory analyzes, was set as a parameter of comparison. In relation to this conventional process, it was tried to demonstrate the possible use of methodologies based on spectral data. This spectral method was evaluated in two moments, the first one based on field samples evaluated by a laboratory hyperspectral sensor, 
specific to this type of research, and the second based on samples collected by means of an orbital multispectral image corresponding to the study area (Landsat7 ETM+). The decision to use two methods of spectral analysis was based on the availability of sensors for this purpose, since a laboratory hyperspectral sensor may not always be available to all researchers, while the multispectral images in question are made available via internet for free for the entire scientific community.

\section{Methodology}

The chosen study area is located in the northwest of Paraná, in a portion of the Querência do Norte district, bounded by geographical coordinates $22^{\circ} 30^{\prime}$ to $23^{\circ} 25^{\prime}$ south latitude and $52^{\circ} 45^{\prime}$ to $53^{\circ} 45^{\prime}$ west longitude (Figure 1 ). The region's soils, although they are formed by the same source material (derived sediment sandstone), vary greatly in composition (Chicati et al. 2010).

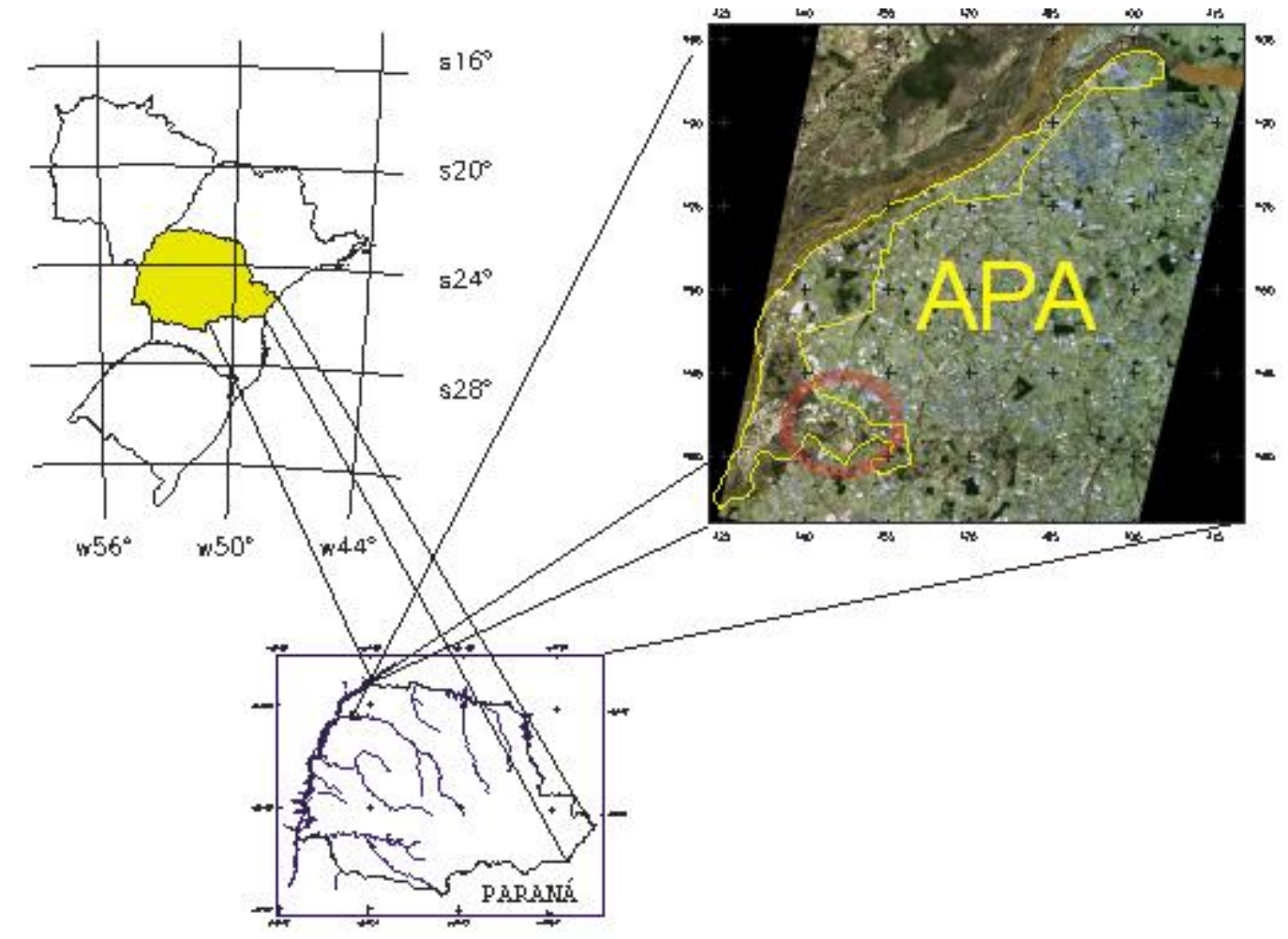

Figure 1: Study area location on south region of Área de Proteção Ambiental das Ilhas e Várzeas do Rio Ivaí.

The geology of the study area is located in the "Unidade Rio Paraná", and has a strongly asymmetrical shape, with a thickness varying from 5 to 6 meters in the portion corresponding to the floodplain. Three faciological associations make up these deposits: 1) sandy polymictic gravel; 2) stratified and sequestered sand; and 3) sandy mud (Stevaux 2009). The study area is located near the Ivaí River, being distributed over the three distinct sections of this same river, which are the basalts of the Formação Serra Geral, sandstones of the Formação Caiuá, and the sediments of the Bacia Sedimentar do Paraná. Within this unit, the sandstones from the Caiuá Formation stand out in the area. These sandstones are basically thin to very thin, layered quartzites, sometimes 
quite friable. In the region of studies, it is possible to identify an association of solid sandstones with medium to small tabular bodies and plane-parallel stratification (Santos and Gasparetto 2008).

The soil map of the study area (Chicati 2010), at a scale of 1:70.000 was also used to determine the most representative sampling points, which is much more detailed than the scale used by Embrapa (2006) of 1:5.000.000. The identification of formations from geomorphological processes, such as the presence of palaeodactic and paleocannal, made by observations of orbital images and also in the field, demonstrated the character of a region submitted to quite singular processes of formation, that are characteristic in the distinction of some units physiographic and also pedological in the field. Then, the soil map in conjunction with the geological and geomorphological analyzes was the basis for the choice of the points sampled in the field.

To determine the soil classes 72 sampling points were selected in field, both surface and subsurface, with sample density of 1 point every 25 ha (rigid mesh of 500x500 meters), as advocated by Lemos and Santos (1996). The samples were sent to the laboratory where chemical and physical attributes were determined in TFSA (Fine dry earth), according to the model proposed by Embrapa (1997). The hydrometer method was used to determine the levels of total sand, silt, and clay. The content of organic matter (OM) was determined by the organic carbon determination process, where the organic matter oxidation was carried out in a sulfuric environment; active and effective acidity was released by reaction in buffered solution of $\mathrm{HCl} ; \mathrm{pH}$ was obtained by measuring the electronic potential with electrode combined immersed in suspension soil:liquid; for determination of cation exchange capacity (CEC) and exchangeable bases (calcium, magnesium, potassium; (S) the adsorbed cations were removed by saline solutions of ammonium, calcium, barium and solutions of dilute acids and later determined by volumetric, emission or atomic absorption methods; base saturation (V\%); and aluminum saturation (m\%); all determinations were determined by using methods recommended by Embrapa (1997). In addition, the soil textural groups were defined according to Embrapa (2006). The soil classification was performed in every single sample point according to Embrapa (2006) and chemical and physical attributes were determined.

After that, each cell $\left(250,000 \mathrm{~m}^{2}\right)$ was assigned with different color representation in accordance with its class of soil. For soil, spectral analyzes sub-samples of surface and subsurface horizons from every sample points were separated, totaling 144 samples. Each soil sample was placed on Petri dishes with $9 \mathrm{~cm}$ diameter. Then ASD spectroradiometer Fieldspec Pro with spectral resolution of $1 \mathrm{~nm}$ between 350 and $1100 \mathrm{~nm}$ and $2 \mathrm{~nm}$ between 1.100 and $2.500 \mathrm{~nm}$ was used to perform the spectral data acquisition. The geometry of data acquirement was composed by: standard white plate with calibrated reflectance at 100\% (Spectralon panel - Labsphere ${ }^{\circledR}$ ); noncollimated light source (halogen Lamp $600 \mathrm{~W}$ with parabolic reflector connected to a stabilizing source of high precision with $220 \mathrm{~V}$ input and output set at $110 \pm 0.5 \mathrm{~V}$ rated voltage and 5.2 amperes; and soil samples. The angle of view was $25^{\circ}$ and the angle between light source and the samples was $62^{\circ}$. The light source was positioned $72 \mathrm{~cm}$ far from the samples and the spectroradiometer $7 \mathrm{~cm}$ far from them. The spectral data acquisition was performed according to Demattê et al. (2004). The first procedure to composition of the data sheet that was used for further analysis was the selection of bands (22) and heights (Reflection Interval Difference) (13), according to methodology proposed by Nanni and Demattê (2006).

Two other procedures were performed in order to obtain parameters that could better explain the differences in spectral behavior between the spectral curves (graphs showing the relation "wavelength $\mathrm{x}$ reflectance factor" of samples) of the different soils analyzed. The first method was 
performed to obtain the tangent value of the initial angle formed by the beginning of the spectral curve and its point of maximum reflectivity (Figure $2 a$ ). The second method took into account the area formed by inflection of two different points in the spectral curve: inflection of water at 1900 $\mathrm{nm}$ and the inflection of kaolinite $2265 \mathrm{~nm}$, common to all samples analyzed in this study (Figure 2b) (Chicati et al. 2017). A simulation procedure of Landsat7 ETM+ bands (1, 2, 3, 4, 5 and 7) in its complete wavelength was also conducted to compare the spectral mapping described above. This simulation of bands of the ETM+ sensor served as a parameter of comparison relative to the spectral data, where on one side were the data strictly obtained in laboratory (simulated bands) and on the other hand the data obtained by spectroradiometry (based on samples collected in the field).
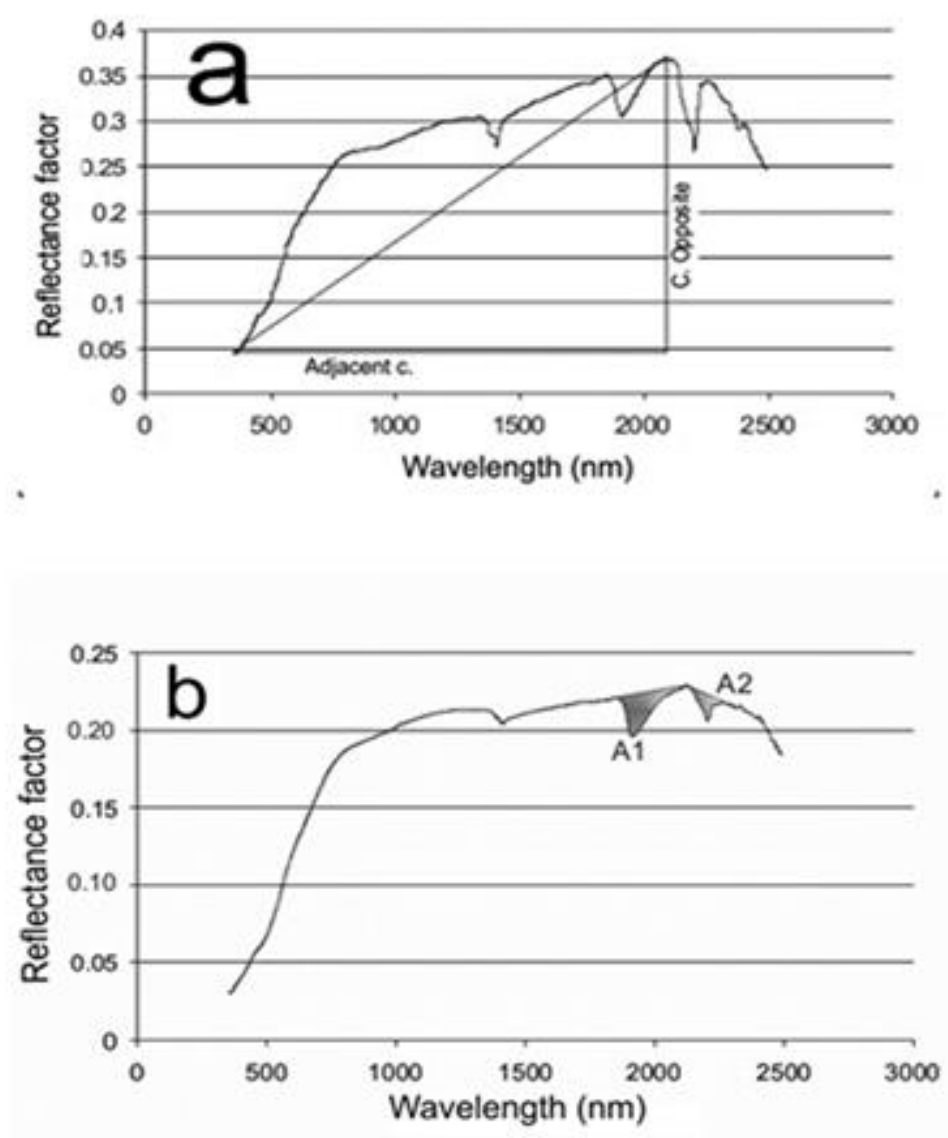

Figure 2: Representative procedure for calculating the tangent (a) and inflection areas (b) on soil spectral curves.

These two methods were used as an attempt to generate new parameters for sample separation since they are conditions that vary across all samples and can demonstrate points in common for similar data. This area was determined with the aid of a tablet and SPRING (Câmara et al. 1996) software for calculation. SPRING is a free GIS software and was used for its accuracy in working with spatial data, including area measurement. Each spectral curve was plotted on paper and properly defined each peak point in succession.

Statistical analysis was performed using the Statistical Analysis System software (SAS 2008). In this system, each sampled point was positioned in a matrix indicated by the expression $X=(X i j)$, where the dimensions form $n$ and $p$, where $n$ indicated the individuals and $p$ the variables (bands, heights and tangent areas). Based on this configuration, we sought to define homogeneous groups that 
could be graphically identified in the form of a map of cells corresponding to the soil classes identified by the variables. The method chosen to define these groupings was the "Average Linkage" with definition of Clusters. Cluster analysis was used to group the variables into classes of similar objects. A cluster is a collection of objects that are similar to each other (according to some predetermined similarity criterion) and dissimilar to objects belonging to other clusters. With the statistically grouped data, maps with the spatial distribution were generated based on the location of each sampling point, as well as done by Zelikman and Carmina (2013). After this distribution, the reliability of this associative method was evaluated, using an independence data analysis, which in this case was based on the Chi-square test (Plackett 1983). In this way, we tried to compare the distribution between the soil classes and the groups defined by the coefficient of similarity. Thus, it was possible to evaluate the observed proportions between the data crossings and to define the possible significant differences.

A fluxogram describing the entire methodological process for obtaining the information, generally speaking, can be seen in Figure 3. Here we can observe that aerial photographs of the study area were used to identify different geological compartments besides relief formations, as mentioned before. In this way we tried to identify regions where possibly different classes of soil would be present. Associated with this photointerpretation analysis was also the georeferencing of a Landsat7 image to locate the points collected in the field by GPS and the definition of the landscape units. The use of Landsat 7 images in this process was important because of their availability in years closer to this study, while the available aerial photographs dated approximately 30 years, which could make it difficult to identify modifications in the local morphology. These conjugated processes aided in the elaboration of the georeferenced database of the study area. This data base was later used to compile the distribution maps of the soil classes. 


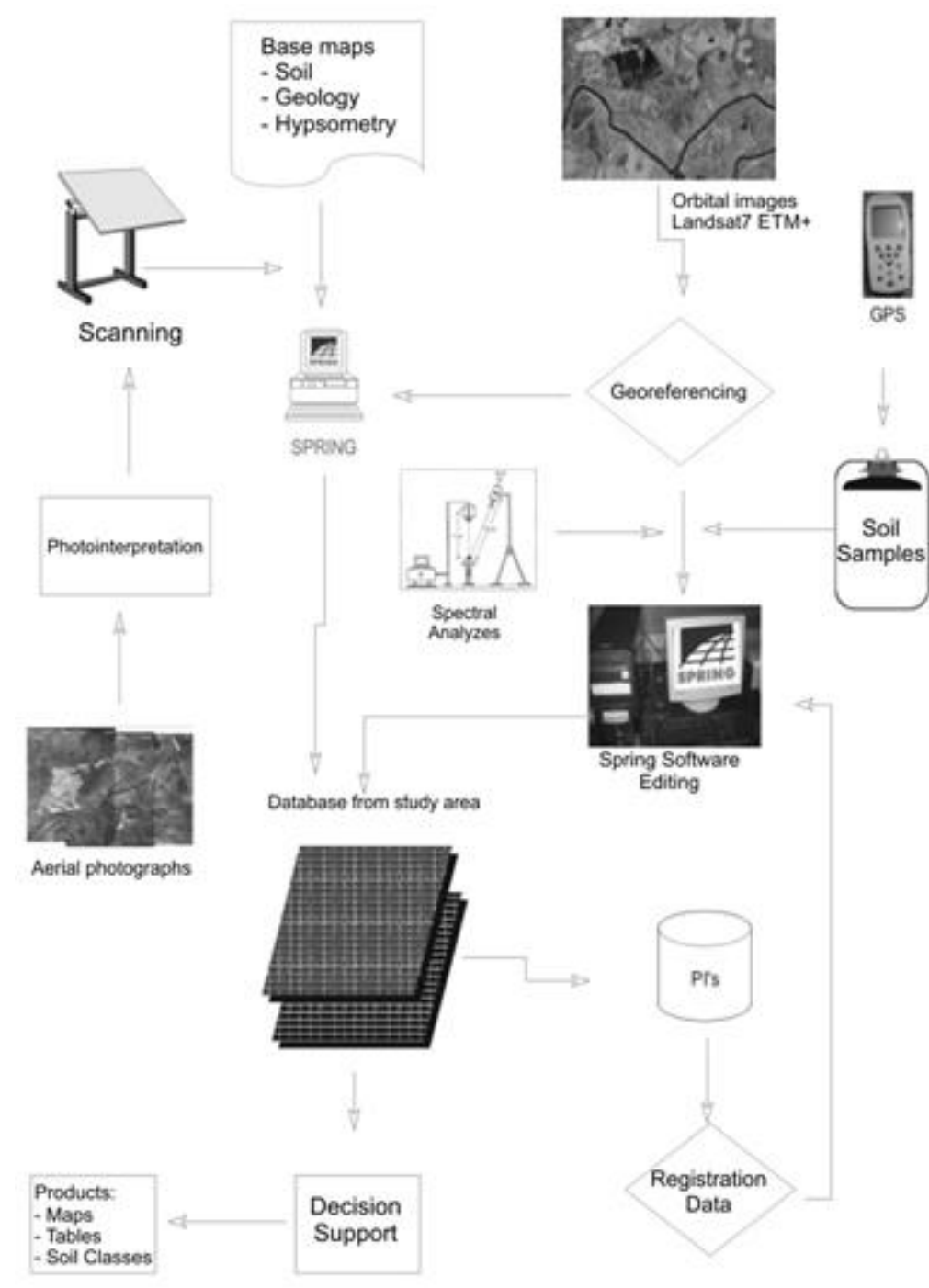

Figure 3: Fluxogram of sequence work: Incorporation of field and laboratory data, editing and evaluation of results obtained.

\section{Results and discussions}

The distribution of soil classes in the study area showed a predominance of young soils with relatively recent formation, considering the local geomorphology and the absence of advanced weathering processes. No aquatic conditions were observed in the studied soils since these underwent variations of the water table only in sporadic periods.

Making use of conventional soil classification it was observed the presence of the following soil classes (Embrapa 2006) and corresponding class in the soil taxonomy (Soil Survey Staff 2014) between brackets: Argissolo Vermelho-Amarelo eutrófico gleico (PVAe) (Ultisol); Argissolo Vermelho-Amarelo distrófico gleico (PVAd) (Ultisol); Neossolo Quartzarênico hidromórfico (RQg) (Entisol); Neossolo Flúvico Ta eutrófico (RYve) (Entisol); Neossolo Flúvico Ta distrófico (RYbd) (Entisol); Plintossolo Pétrico litoplíntico (FFlf) (Alfisol); Plintossolo Pétrico concrecionário eutrófico (FFce) (Alfisol); Organossolo Háplico fíbrico (OXfi) (Histosol); Cambissolo Háplico alumínico (CXa) (Inceptisol); e Latossolo Vermelho-Amarelo distrófico (LVAd) (Oxisol). Since the Brazilian System 
Soil classification (Embrapa 2006) classifies the soil by the characteristics of its subsurface (subsurface horizons), the spectral evaluation aimed to obtain the correlation between these characteristics (chemical or physical), and the spectral response of these soils regarding to their attributes on subsurface (Figure 4).

\section{Soil Classes - Spectral Curves}

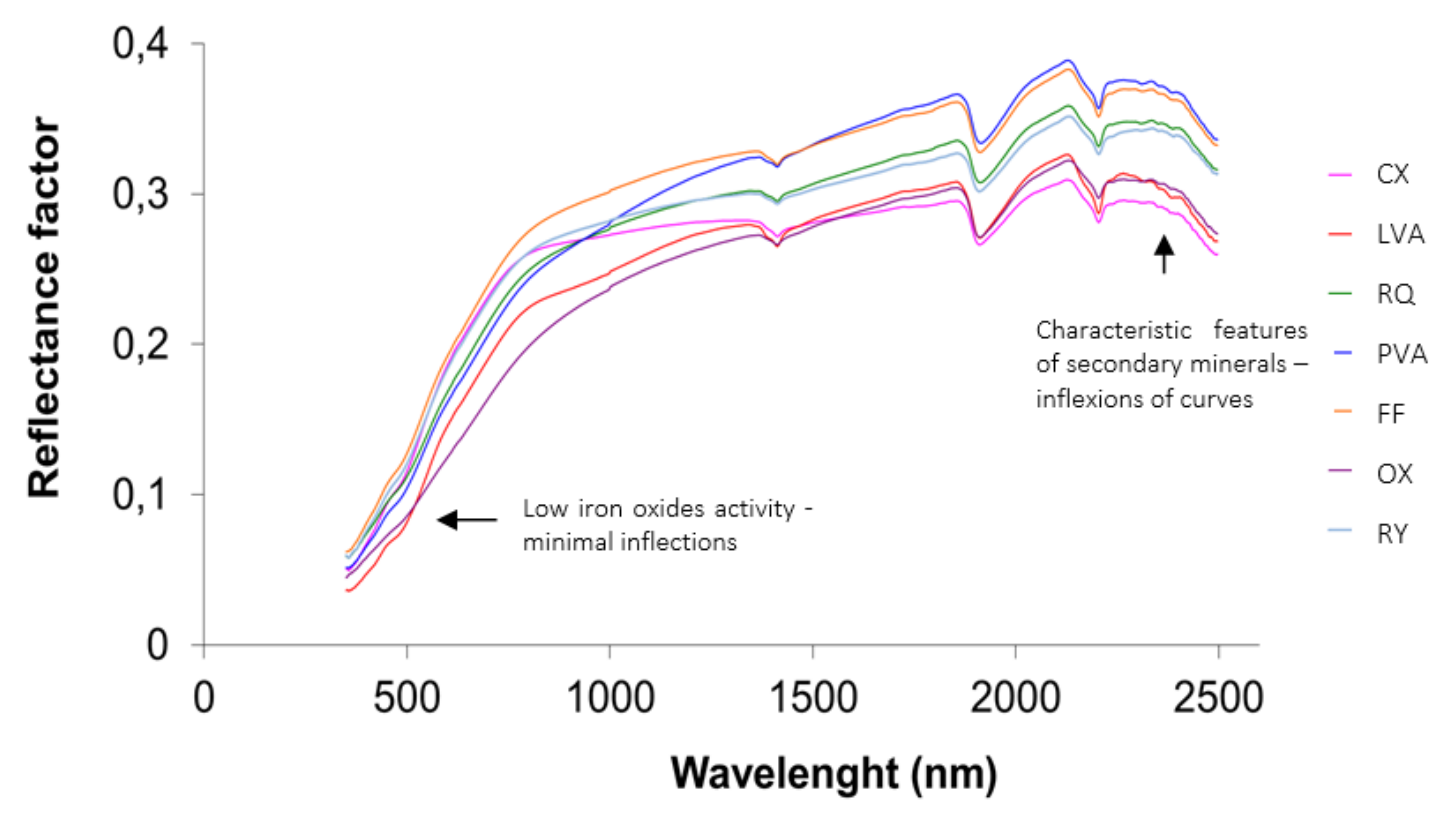

CX: Inceptisols; LVA: Oxisols; RQ: Entisols; PVA: Ultisols; FF: Alfisols; OX: Histosols; RY: Entisols (Fluvents).

Figure 4: Spectral reflectance profiles acquired with FieldSpec in the spectral range of $350-2500$ $\mathrm{nm}$ to representing the soil classes and features.

Once observed the lack background and previous studies for the study area, priority was given to the distinction and comparison of soil classes only at the order level, highlighting possibilities for future insights. In the maps, both the conventional and the spectral, soil classes were considered only in the first category level due to the reduced number of available samples (144), the same number of samples used for statistical analysis (Figure 5). 


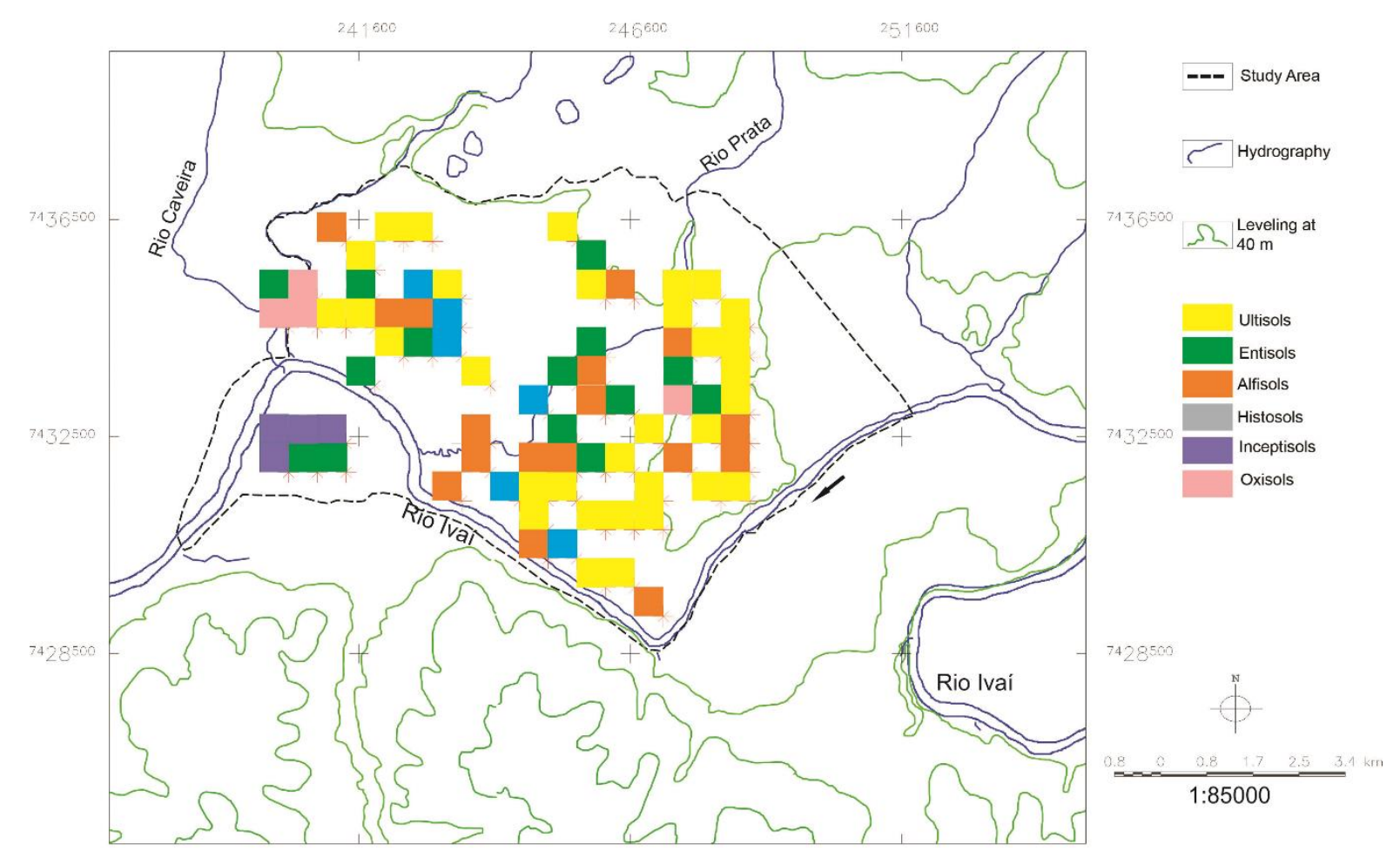

Figure 5: Study Area Soil Map produced by rigid mesh method.

Figure 5 shows a heterogenous spatial distribution of the soil classes in the study area. This can be explained by geological analysis and hence of the source material in the region (Santos and Gasparetto 2008; Stevaux et al. 2009, Arruda et al. 2016). Factors such as water table fluctuation, drying and wetting successions, constant deposits of organic matter or even seasonal flooding conditions can be mentioned here as decisive in the formation and alteration of local soils, as already observed by Chicati (2017). The soil maps obtained by laboratory spectral data analysis were based on cluster analysis of the bands, heights, tangent and areas delimited on the spectral laboratory curves. Examination of the resulting dendrogram of this analysis allowed distinction of groups corresponding to the clusters of soil sampling points. Those analyses allowed the identification of eight distinct groups (G1 to G8) among the sample points. For this dismemberment of groups, we used a similarity coefficient of 0.42 , determined by hierarchical cluster analysis. Based on the information of the groups formed by statistical analysis, each sample point was then separated into each group. After that, each sample point was represented in the soil map according to the group in that it has been classified. Thus, it was possible to obtain the map of Figure 6. 


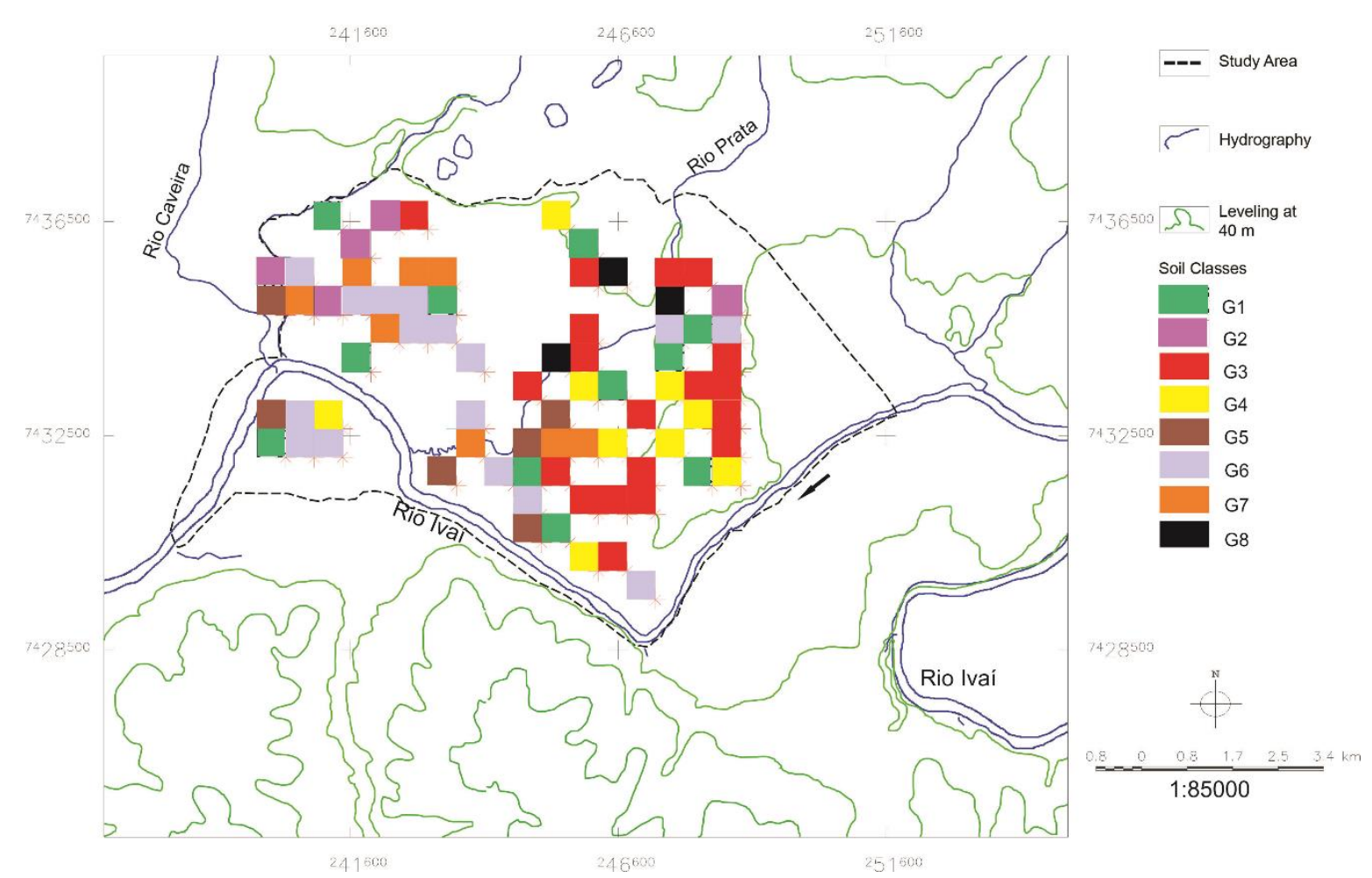

Figure 6: Soil Map of the study area obtained by cluster analysis of spectral data with bands, heights, tangent and obtained areas using the sensor Fieldspec (spectroradiometer with 350$2500 \mathrm{~nm}$ spectrum).

By the observation of Figure 6 there was no relationship between the clusters generated by multivariate analysis and soil classes found in the field by conventional methodology, confirming the difficulty of cartographic representation of the wide range of neighboring classes already observed by Cook et al. (1996). Eight clusters were obtained by clustering analysis, larger number when compared to the soil classes(six). This demonstrates that no direct association was found between spectral analysis of the clusters and the commonly soil classification. Instead, it wasn't observed a specific distribution of individuals with similar spectral characteristics such as the reflectance factor, which is the ratio of electromagnetic energy reflected by the body and the electromagnetic energy reflected by a standard surface, or amplitude of the entire curve (Franceschini et al. 2015; Chicati et al. 2017). It was also possible to infer that the groups had different behaviors for certain soil classes, comprising all, as group 6, or only two, as group 8 , shown in Table 1. 
Table 1: Soil classes obtained by conventional methodology and groups obtained by statistical analysis with use of the bands, heights, tangent and areas.

\begin{tabular}{c|c|c|c|c|c|c|c|c}
\hline Classes & $\mathrm{G} 1$ & $\mathrm{G} 2$ & $\mathrm{G} 3$ & $\mathrm{G} 4$ & $\mathrm{G} 5$ & $\mathrm{G} 6$ & $\mathrm{G} 7$ & $\mathrm{G} 8$ \\
\hline Argissolo & 4 & 4 & 8 & 3 & 1 & 3 & 4 & 0 \\
\hline Neossolo & 3 & 1 & 1 & 1 & 0 & 4 & 1 & 2 \\
\hline Plintossolo & 0 & 1 & 5 & 2 & 2 & 6 & 1 & 1 \\
\hline Latossolo & 1 & 0 & 0 & 0 & 1 & 1 & 1 & 0 \\
\hline Organossolo & 2 & 0 & 0 & 0 & 1 & 1 & 1 & 0 \\
\hline Cambissolo & 1 & 0 & 0 & 1 & 1 & 1 & 0 & 0 \\
\hline
\end{tabular}

The observation of Figure 6 together with the distribution of groups allows some inferences about the relative positioning of these groups, mainly in relation to the physiographic conformation of the terrain, which can be observed, for example, for groups G4 and G5, predominant in more flat terrain. The observation of the map and the allocation of the clusters was a possible relation of the positioning of these groups with the physiographic distribution of the terrain, with a predominance, for example, of groups 4 and 5 in the flattest region of the area. The practically random behavior of the distribution of the clusters in this model can also be attributed to the great diversity of soil classes present in a small area (Chicati 2010). However, the chi-square test performed with data of the combination of soil classes and the eight selected groups demonstrated, in $5 \%$ significance level, that there is a positive association between the two sets of variables, i.e., there is real relationship dependence (calculated $X_{1}^{2} 31.969 ; X_{1}^{2}$ tabulated 31.410). Another map was produced using data extracted from the laboratory spectral curves, simulating the 6 spectral bands present in the orbital sensor TM-Landsat. The selection of the groups was performed in the same way as the first map (Figure 4). As in the previous model, 8 groups were founded with coefficient of similarity this time amounting to 0.49 . The selected classes were distributed into groups and represented as in the previous map (Figure 7). 


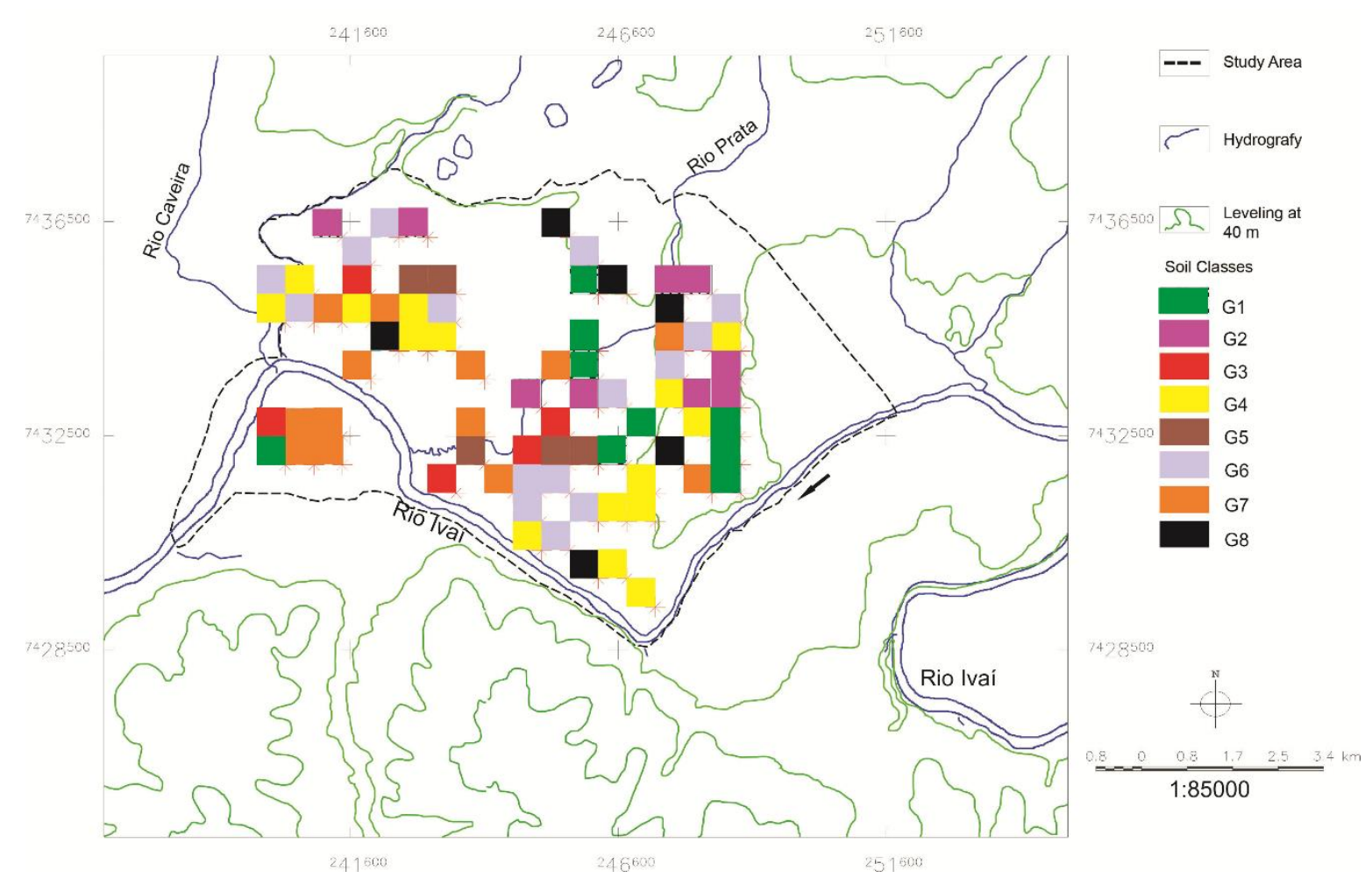

Figure 7: Soil map of the study area obtained by spectral data groups with the bands of Landsat TM-simulated using the Fieldspec sensor (spectroradiometer in the 350-2500 nm range).

In Figure 7 is evident better randomized distribution than the previous one, and the largest gap between the location of groups within the geographical area (Minasny and McBratney 2016). The comparison between the groups obtained in this method and soil classes identified by conventional methodology obtained as recommended by Fiorio and Demattê (2009), is presented in Table 2.

Table 2: Relationship between soil classes obtained by conventional methodology and groups obtained by statistical analysis based on simulation of the TM-Landsat sensor bands.

\begin{tabular}{c|c|c|c|c|c|c|c|c}
\hline Classes & $\mathrm{G} 1$ & $\mathrm{G} 2$ & $\mathrm{G} 3$ & $\mathrm{G} 4$ & $\mathrm{G} 5$ & $\mathrm{G} 6$ & $\mathrm{G} 7$ & $\mathrm{G} 8$ \\
\hline Argissolo & 3 & 7 & 1 & 2 & 3 & 6 & 3 & 2 \\
\hline Neossolo & 1 & 1 & 1 & 1 & 0 & 2 & 5 & 2 \\
\hline Plintossolo & 4 & 3 & 2 & 3 & 1 & 0 & 3 & 2 \\
\hline Latossolo & 0 & 0 & 0 & 2 & 0 & 2 & 0 & 0 \\
\hline Organossolo & 0 & 0 & 0 & 2 & 1 & 2 & 0 & 0 \\
\hline Cambissolo & 1 & 0 & 1 & 0 & 0 & 0 & 2 & 0 \\
\hline
\end{tabular}

The number of classes covered by these currently methods was greater than the existing map (Figure 8), even considering only the first categorical level of classification, and is therefore a relevant complement to the available information (Embrapa 2006). 


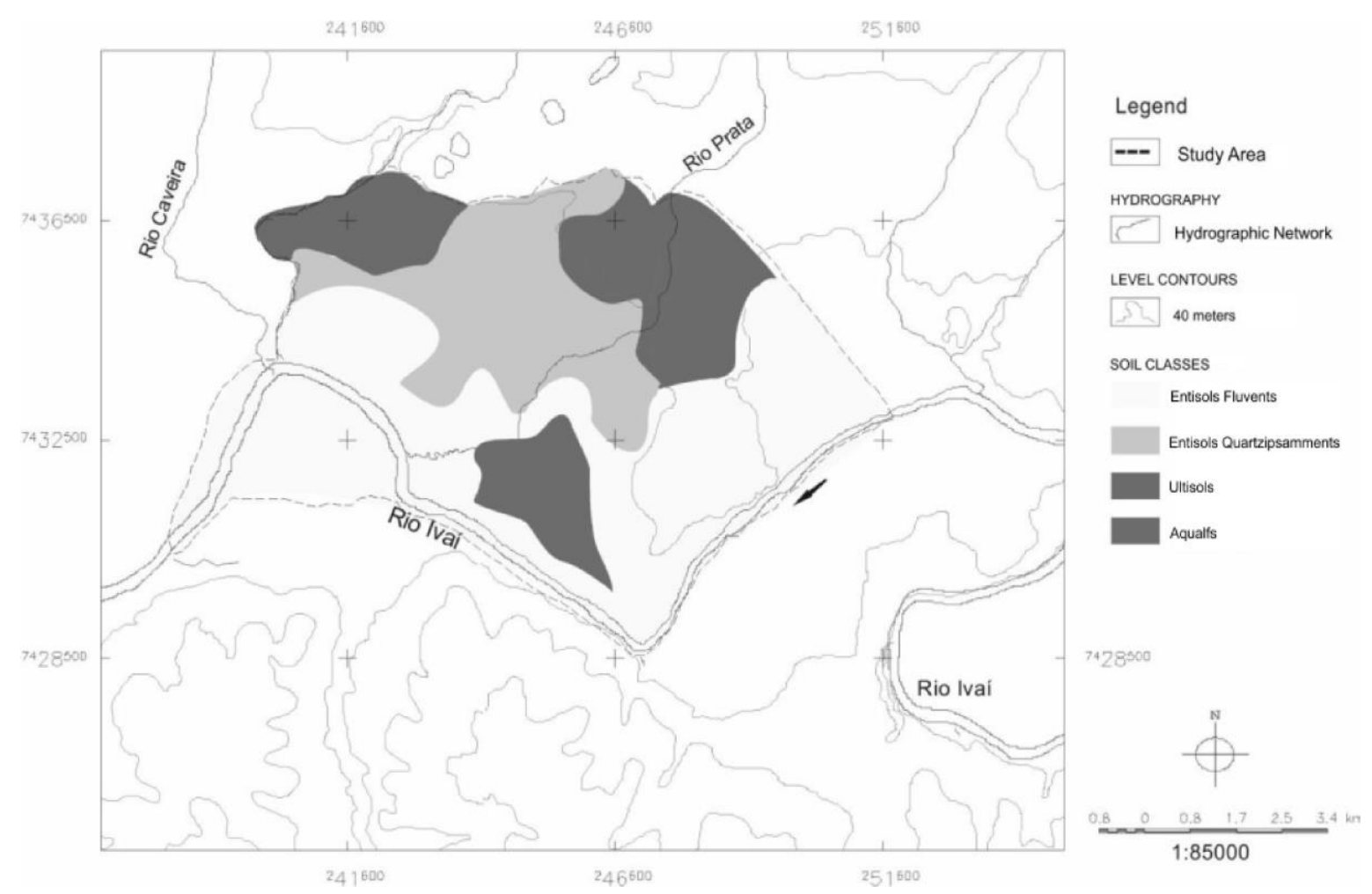

Figure 8: Soil map of the area compiled of the study by EMBRAPA (2006).

The greater diversification of soil classes distribution for groups is characterized in the class of Argissolos, which has at least one individual in each group. This fact can be explained by the most prevalence of this class which is also geographically distributed in several geomorphological compartments, as noted by Chicati et al. (2010). As observed in the first map produced with spectral data, this one also showed parity between the distribution of groups in relation to the physiographic compartmentalization of the area, showing that the local environment has an influence on the information produced by this method also confirmed by Embrapa (2006). As in the previous methodology, the chi-square test showed the occurrence. at $5 \%$ of significance, of dependence between the two correlated groups evaluated, with positive association between the data (calculated $X_{1}^{2} 40.172 ; X_{1}^{2}$ tabulated 31.410). The demonstration of positive correlation based on these analyzes of independence between the groups confirms the hypothesis that it is possible to map paddy soils by means of spectral data, both of laboratory origin and orbital origin. Although the degree of correlation between methods has not been evaluated, positive statistical confirmation evidences the possibility of carrying out new studies to quantify this correlation.

\section{Conclusions}

Soil mapping using its spectral curves representing the interaction between the reflected energy and the material contained in its composition was successful, with varying levels of correlation, depending on the pedological unit, compared to the conventional mapping. Thus, it became clear that the soil maps produced with spectral data and conventional methodology have related regions and, therefore, can be used for similar purposes. The model used for testing the procedure for mapping soils had high levels of accuracy relative to that reported in previous work. However, the results were representative of the unique conditions of the study area. Because it is still a little 
used methodology, it would be interesting that new studies were carried out to quantify economically the efficiency of the process.

\section{ACKNOWLEDGEMENT}

The National Council of Scientific and Technological Development, the granting of scholarship to the first author (Proc. N. 143399/2009-8) and productivity scholarship (Proc. N.310948/2006-1) to the second author.

\section{REFERENCES}

Arruda, G. P. D. et al. 2016. Digital soil mapping using reference area and artificial neural networks. Scientia Agricola, 73(1), pp.266-273.

Brandão, A.S.P. et al. 2006. Crescimento agrícola no período 1999/2004: a explosão da soja e da pecuária bovina e seu impacto sobre o meio ambiente. Economia Aplicada, 10(1), pp.249-266.

Câmara, G. et al. 1996. SPRING: Integrating remote sensing and GIS by object-oriented data modelling. Computers \& graphics, 20(3), pp.395-403.

Chicati, M. L. et al. 2008. Caracterização de alguns atributos do solo e sua correlação com a paisagem em uma porção do noroeste do Estado do Paraná. Acta Scientiarum Agronomy, 30 (1), pp.719-24.

Chicati, M. L. et al. 2010. Modelagem de um complexo de inundação por meio de sistema de informações geográficas. Bragantia, 69 (1), pp.485-91.

Chicati, M. L. et al. 2017. Spectral classification of soils: A case study of Brazilian flooded soils. Remote Sensing Applications: Society and Environment, 6 (5), pp.39-45.

Cook, S. E. et al. 1996. A Rule-based system to map soil properties. Soil Science Society of America Journal, 60 (2), pp.1893-1900.

Demattê, J. A. M. et al. 2004. Metodologia para reconhecimento de três solos por sensores: laboratorial e orbital. Revista Brasileira de Ciência do Solo, 28 (1), pp.877-89.

Embrapa. 1997. Manual de métodos de análises de solo. Rio de Janeiro: Ministério da Agricultura e do Abastecimento.

Embrapa. 2006. Sistema Brasileiro de Classificação de Solos. Rio de Janeiro: Centro Nacional de Pesquisa de Solos.

Fiorio, P. R. and Demattê, J. A. D. 2009. Orbital and laboratory spectral data to optimize soil analyses. Scientia Agrícola, 66 (1), pp. 250-57.

Franceschini, M. H. D. et al. 2015. Prediction of soil properties using imaging spectroscopy: Considering fractional vegetation cover to improve accuracy. International Journal of Applied Earth Observation and Geoinformation, 38 (2), pp.358-370.

Lemos, R. C. and Santos, R. D. 1996. Manual de Descrição e Coleta de Solo no Campo. Campinas: Sociedade Brasileira de Ciência do Solo. 
Minasny, B. and McBratney, A. B. 2016. Digital soil mapping: A brief history and some lessons. Geoderma, 264 (1), pp.301-311.

Nanni, M. R. et al. 2004. Análise discriminante dos solos por meio da resposta espectral no nível terrestre. Pesquisa Agropecuária Brasileira, 30 (2), pp.995-1006.

Munyati, C. 2000. Wetland change detection on the Kafue Flats, Zambia, by classification of a multitemporal remote sensing image dataset. International Journal of Remote Sensing, 21(1), pp.1787-1806.

Nanni, M. R. and Demattê, J. A. M. 2006. Spectral reflectance methodology in comparison to traditional soil analysis. Soil Science Society of America Journal, 70 (3), pp.393-407.

Plackett, R. L. 1983. Karl Pearson and the Chi-Squared Test. International Statistical Review, 51 (1), pp.59-72.

Santos, M. L. and Gasparetto, N. V. L. 2008. Minerais pesados dos depósitos aluviais do rio Paraná e sua implicação Paleohidrológica. Revista Pesquisas em Geociências, 35 (2), pp.71-81.

SAS Institute. 2008. SAS, software: user's guide, version 9.0. Cary: SAS.

Soil Survey Staff. 2014. Keys to Soil Taxonomy 12th ed. USDA-Natural Resources Conservation Service: Washington, DC.

Sousa Jr., J. G. A. et al. 2008. Comportamento espectral dos solos na paisagem a partir de dados coletados por sensores terrestre e orbital. Revista Brasileira de Ciência do Solo, 32 (1), pp.727-38.

Stevaux, J. C. et al. 2009. Flow structure and dynamics in large tropical river confluence: example of Ivaí and Paraná rivers, southern Brazil. Geociências, 28 (2), pp.5-13.

Zelikman E. and Carmina, E. 2013. The spectral response characteristics of the soils and their possible estimation by using partial least square regression (PLSR) analysis. International Journal of Geomatics and Geosciences, 3(1), pp.438-453. 